\title{
Metformin and thyroid disease
}

\author{
Xianghui Meng ${ }^{1, *}$, Shuhang $\mathrm{Xu}^{2, *}$, Guofang Chen ${ }^{2}$, Michael Derwahl ${ }^{3}$ and Chao Liu ${ }^{2}$ \\ ${ }^{1}$ Chinese Medicine Hospital in Linyi City, Linyi, China \\ ${ }^{2}$ Affiliated Hospital of Integrated Traditional Chinese and Western Medicine, Nanjing University of Chinese \\ Medicine, Jiangsu Province Academy of Traditional Chinese Medicine, Nanjing, China \\ ${ }^{3}$ Division of Endocrinology, Department of Medicine, St. Hedwig Hospital, Berlin, Germany \\ *(X Meng and S Xu contributed equally as co-first authors)
}

Correspondence

should be addressed

to C Liu

Email

liuchao@nfmcn.com

\begin{abstract}
An intriguing area of research in thyroidology is the recently discovered association of insulin resistance with thyroid functional and morphological abnormalities. Individuals with hyperinsulinemia have larger thyroid gland and a higher prevalence of thyroid nodules and cancer. Accordingly, patients treated with metformin have a smaller thyroid volume and a lower risk of incident goiter, thyroid nodule and cancer. Multiple studies in vitro and in vivo have demonstrated that metformin can inhibit the growth of thyroid cells and different types of thyroid cancer cells by affecting the insulin/IGF1 and mTOR pathways. Besides, metformin treatment was associated with a decrease in the levels of serum thyroid-stimulating hormone (TSH) in diabetic patients possibly by enhancing the effects of thyroid hormones in the pituitary and activating the adenosine monophosphate-activated protein kinase (AMPK). Based on this evidence, metformin appears to be a promising therapeutic tool in patients with thyroid disease. More clinical studies are necessary to evaluate the clinical significance of metformin for the treatment of thyroid diseases.
\end{abstract}

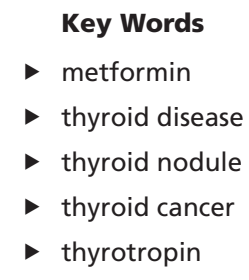

Journal of Endocrinology (2017) 233, R43-R51

\section{Introduction}

Metformin, the most widely used antidiabetic drug, is considered as the cornerstone of type 2 diabetes treatments. Surprisingly, a few years ago, it has been reported that serum TSH level in hypothyroid patients decreased in response to metformin therapy and increased again when metformin was discontinued (Vigersky et al. 2006). Later, this finding has been confirmed by several studies.

The novel effects of metformin on the thyroid were not confined to hypothyroidism. Prospective and retrospective studies showed that patients with prediabetes and type 2 diabetes mellitus $\left(\mathrm{T}_{2} \mathrm{DM}\right)$ had a significantly increased thyroid volume and a higher prevalence of incident goiter and nodules. Furthermore, diabetic patients treated with metformin had a smaller thyroid volume and a lower risk for the formation of thyroid nodules when compared with controls (Anil et al. 2013, Ittermann et al. 2013, Blanc et al. 2015). These results suggested that metformin exerts an anti-proliferative activity, providing a rationale for an innovative therapy of thyroid proliferative diseases with metformin.

\section{Metformin and thyroid function}

\section{Metformin and hypothyroidism}

A retrospective review of 4 patients with chronic hypothyroidism suggested that metformin is involved in reducing TSH level (Vigersky et al. 2006). It is worth noting that this was an isolated effect on TSH 
without any relevant changes in serum thyroxine $\left(\mathrm{T}_{4}\right)$ and triiodothyronine $\left(\mathrm{T}_{3}\right)$ levels. After this first report, great interest has aroused in the effects of metformin on thyroid function in patients with $\mathrm{T}_{2} \mathrm{DM}$. A metaanalysis including 7 studies that evaluated changes in TSH levels in patients receiving metformin, showed a reduction of TSH levels both in overt and in subclinical hypothyroidism, with no change in euthyroid patients (Lupoli et al. 2014).

Following these initial findings, a number of studies were performed to elucidate the effect and mechanism of metformin on TSH level (Table 1). In a longitudinal population-based study, $5689 \mathrm{~T}_{2} \mathrm{DM}$ patients treated for hypothyroidism and 59,937 euthyroid patients with $\mathrm{T}_{2} \mathrm{DM}$ were included (Fournier et al. 2014). Metformin monotherapy was associated with an increased risk of low TSH levels in patients with treated hypothyroidism, whereas this was not observed in euthyroid patients. In a retrospective clinical study, Distiller et al. (2014) revealed an association not only between diabetes and hypothyroidism but also between the metformin therapy and a significantly lower prevalence of diagnosed hypothyroidism.

However, contradictory results have also been reported. A retrospective study was conducted to evaluate the variation in serum TSH level after 1 year of metformin treatment in 278 euthyroid diabetic individuals (SantosPalacios et al. 2015). In this particular population, metformin seemed to induce a 'buffer effect' on TSH secretion as it induced a return in circulating TSH to the middle of its normal range with the threshold point level defined as $2.98 \mathrm{mU} / \mathrm{L}$. In other words, metformin has a lowering effect on TSH level when TSH is higher than $2.98 \mathrm{mU} / \mathrm{L}$, whereas this effect is the opposite in those individuals with a serum TSH level lower than $2.98 \mathrm{mU} / \mathrm{L}$. Karimifar et al. (2014) randomly treated 89 people with prediabetes (impaired fasting blood glucose values of $100-125 \mathrm{mg} / \mathrm{dL}$, and/or 2-h postprandial blood glucose values of $140-199 \mathrm{mg} / \mathrm{dL}$ during OGTT) with metformin or placebo for a period of 3 months. In this double-blind placebo-control clinical trial, metformin treatment was associated with a decrease in the levels of serum TSH only in those patients with TSH $>2.5 \mu \mathrm{U} / \mathrm{mL}$. Furthermore, the aforementioned thyrotropinlowering effect of metformin was not observed in subclinical hyperthyroid subjects with coexistent $T_{2} D M$ (Krysiak et al. 2015). Therefore, the clinical consequences of the effect of metformin treatment on TSH level need further investigations.

\section{Mechanism of action on thyroid function}

Metformin is the most widely prescribed insulinsensitizing agent in diabetic patients; however, cellular and molecular mechanism of metformin action is complex and multifactorial. It is active at all sites of impaired insulin action (Giannarelli et al. 2003). At the level of the liver, metformin increases insulin-mediated suppression of hepatic glucose production, mainly by reducing gluconeogenesis. In skeletal muscle it promotes insulin receptor phosphorylation, glucose transporter (GLUT)- 4 translocation resulting in increased glucose uptake and glycogen synthesis. In adipose tissue, metformin promotes the re-esterification of free fatty acids and inhibits lipolysis, which may indirectly improve insulin sensitivity through reduced lipotoxicity. Thus, many of the metabolic alterations brought about by insulin resistance (IR) are improved by metformin (Giannarelli et al. 2003). Although a number of hypotheses have been put forward, no study has so far elucidated the mechanism in detail.

Metformin is hypothesized to change the affinity and/or quantity of thyroid hormone receptors, increase the central dopaminergic tone or induce activation of the TSH receptor, thus enhancing the effects of thyroid hormones in the pituitary (Vigersky et al. 2006). In a case report of a 28-year-old male with resistance to thyroid hormone, metformin-induced hyperthyroidism, normalized altered circulating levels of peripheral markers of thyroid hormone action and required a temporary reduction in the levothyroxine dose (Krysiak \& Okopien 2011). The interesting finding suggested that metformin may modulate hypothalamic-pituitary-thyroid axis activity at the levels of peripheral tissues and by its impact on the thyroid gland itself.

In a recent prospective clinical trial including 24 prediabetic patients with polycystic ovary syndrome (PCOS) and untreated subclinical hypothyroidism, 12 patients had already been treated with bromocriptine. After metformin treatment of all patients for 6 months, thyrotropin-lowering effect of metformin was stronger in patients not treated with bromocriptine than that in patients receiving bromocriptine. The results indicated that metformin treatment may have an impact on thyrotropin function in hypothyroid patients, in part, associated with the changes in dopaminergic regulation of thyrotropin secretion and is less pronounced in patients receiving bromocriptine treatment (Krysiak \& Okopien 2015). Recently, metformin was found to be able to cross the blood-brain barrier (BBB) in rat and

Published by Bioscientifica Ltd. 
Table 1 Summary of studies on metformin and thyroid function.

\begin{tabular}{l} 
Study type \\
\hline Retrospective stud \\
Three-month \\
prospective stu
\end{tabular}

One-year case-
control study

Six-month prospective placebo-controlled study

Four months casecontrol study

Retrospective study

Retrospective study

Retrospective study

Longitudinal population-based study

Retrospective study
Overweight and obese subjects with or without diabetes

Population
Patients with chronic
hypothyroidism on fixed doses
of $\mathrm{L}_{4}$

Obese, diabetic postmenopausal 8 individuals women with primary hypothyroidism

Diabetic patients including euthyroid patients on $\mathrm{L}-\mathrm{T}_{4}$ substitution, subclinical hypothyroid patients who did not receive $\mathrm{L}_{\mathrm{T}}$ treatment and euthyroid patients

Overweight women with PCOS and primary subclinical hypothyroidism

Patients with PCOS, including hypothyroidism treated with levothyroxine, untreated subclinically hypothyroidism, euthyroid

Euthyroid diabetic patients, including subjects never treated with metformin and $\mathrm{L}^{-} \mathrm{T}_{4}$; subjects started metformin treatment at recruitment; patients on L- $\mathrm{T}_{4}$ who started metformin recruitment Euthyroid patients with $\mathrm{T}_{2} \mathrm{DM}$ females

$\mathrm{T}_{2} \mathrm{DM}$ patients with or without hypothyroidism

$\mathrm{T}_{2} \mathrm{DM}$ patients with or without hypothyroidism

\begin{tabular}{l} 
Numbers \\
\hline 4 individuals \\
8 individuals
\end{tabular}

101 individuals

27 individuals

33 individuals

393 individuals

108 individuals

\section{patients with}

A total of 5689 treated hypothyroidism and 59,937 euthyroid patients were included in the subcohorts

922 individuals

\section{Summary of findings \\ Initiation of treatment with metformin caused suppression \\ Reference \\ Vigersky et al. \\ 2006} of TSH to subnormal levels.

Short-term metformin administration is associated with a significant fall in TSH in obese, diabetic patients with primary hypothyroidism on thyroxine replacement treatment.

A significant TSH decrease associated with metformin administration was observed in diabetic subjects with hypothyroidism who were either treated or untreated with $\mathrm{L}^{-\mathrm{T}_{4}}$, but not in euthyroid subjects.

In overweight PCOS patients with primary hypothyroidism, treatment with metformin resulted in a significant fall in TSH.

Metformin administration has a TSH-lowering effect in diabetic patients on $\mathrm{L}^{-} \mathrm{T}_{4}$ treatment and shows a significant reduction of TSH also in euthyroid patients with higher baseline. Metformin administration has a TSH-lowering effect in diabetic patients on $\mathrm{L}^{-} \mathrm{T}_{4}$ treatment and shows a significant reduction of TSH also in euthyroid patients with higher baseline.

Metformin administration has no relationship between TSH values and thyroid function in euthyroid $\mathrm{T}_{2} \mathrm{DM}$ patients.

Metformin treatment seems to affect thyroid function in diabetic patients by maintaining plasma thyrotropin levels to subnormal levels.

Metformin use was associated with an increased incidence of low TSH levels in patients with treated hypothyroidism, but not in euthyroid patients. The clinical consequences of this need further investigation.

The use of metformin therapy in people with $\mathrm{T}_{2} \mathrm{DM}$ diabetes was associated with a significantly lower prevalence of diagnosed hypothyroidism.
Isidro et al. 2007

Cappelli et al. 2009

Morteza Taghavi

et al. 2011

Rotondi et al.

2011

\section{Cappelli et al.}

2012

Díez \& Iglesias

2013

Kouidhi et al.

2013

Fournier et al.

2014

Distiller et al.

2014

(Continued) http://joe.endocrinology-journals.org DOI: 10.1530/JOE-16-0450
๑) 2017 Society for Endocrinology Printed in Great Britain
Published by Bioscientifica Ltd 
Table 1 Continued.

\begin{tabular}{|c|c|c|c|c|}
\hline Study type & Population & Numbers & Summary of findings & Reference \\
\hline $\begin{array}{l}\text { Three-month } \\
\text { placebo-controlled } \\
\text { clinical trial }\end{array}$ & Prediabetic people & 89 individuals & $\begin{array}{l}\text { In prediabetic people, } \\
\text { metformin decreases serum } \\
\text { TSH, only, in those people with } \\
\text { TSH }>2.5 \mu \mathrm{U} / \mathrm{mL} \text {. }\end{array}$ & $\begin{array}{l}\text { Karimifar et al. } \\
2014\end{array}$ \\
\hline Retrospective study & Patients without hypothyroidism & 278 individuals & $\begin{array}{l}\text { Metformin seems to induce a } \\
\text { 'buffer effect' on TSH } \\
\text { secretion in euthyroid diabetic } \\
\text { individuals. }\end{array}$ & $\begin{array}{l}\text { Santos- } \\
\text { Palacios et al. } \\
2015\end{array}$ \\
\hline $\begin{array}{l}\text { Three- and 6-month } \\
\text { of prospective study }\end{array}$ & $\begin{array}{l}\mathrm{T}_{2} \mathrm{DM} \text { patients with subclinical } \\
\text { hyperthyroidism }\end{array}$ & 42 individuals & $\begin{array}{l}\text { Metformin has a negligible } \\
\text { effect on hypothalamic- } \\
\text { pituitary-thyroid axis activity } \\
\text { in } T_{2} \text { DM patients with } \\
\text { subclinical hyperthyroidism. }\end{array}$ & Krysiak et al. 2015 \\
\hline $\begin{array}{l}\text { Six-month } \\
\text { prospective study }\end{array}$ & $\begin{array}{l}\text { Prediabetic patients with } \\
\text { polycystic ovary syndrome and } \\
\text { untreated subclinical } \\
\text { hypothyroidism }\end{array}$ & 24 individuals & $\begin{array}{l}\text { Metformin treatment may have } \\
\text { an impact on thyroid function } \\
\text { in hypothyroid patients, } \\
\text { probably by enhancing the } \\
\text { effect of thyroid hormone } \\
\text { action in the pituitary. }\end{array}$ & Krysiak et al. 2015 \\
\hline $\begin{array}{l}\text { Six-month } \\
\text { prospective study }\end{array}$ & $\begin{array}{l}\text { Amiodarone-treated patients } \\
\text { with } \mathrm{T}_{2} \mathrm{DM} \text { patients: patients } \\
\text { with treated overt } \\
\text { hypothyroidism, patients with } \\
\text { untreated subclinical } \\
\text { hypothyroidism }\end{array}$ & 48 individuals & $\begin{array}{l}\text { The obtained results indicate } \\
\text { that the effect of metformin } \\
\text { on hypothalamic-pituitary- } \\
\text { thyroid axis activity is partially } \\
\text { related to thyroid function. } \\
\text { Metformin treatment may } \\
\text { bring clinical benefits to } \\
\text { patients with amiodarone- } \\
\text { induced hypothyroidism and } \\
\text { poor tolerance of exogenous } \\
\text { L-thyroxine. }\end{array}$ & $\begin{array}{l}\text { Krysiak et al. } \\
2016 a\end{array}$ \\
\hline $\begin{array}{l}\text { Four-month Pilot } \\
\text { study }\end{array}$ & $\begin{array}{l}\text { Two matched groups of women } \\
\text { with type } 2 \text { diabetes and } \\
\text { untreated subclinical } \\
\text { hypothyroidism }\end{array}$ & 20 individuals & $\begin{array}{l}\text { The effect of metformin on } \\
\text { serum thyrotropin was } \\
\text { stronger in patients with } \\
\text { interferon-induced thyroiditis } \\
\text { than in patients with } \\
\text { Hashimoto's thyroiditis, as well } \\
\text { as correlated with its impact } \\
\text { on insulin sensitivity. }\end{array}$ & $\begin{array}{l}\text { Krysiak et al. } \\
2016 b\end{array}$ \\
\hline $\begin{array}{l}\text { Four-month } \\
\text { prospective study }\end{array}$ & $\begin{array}{l}\text { Patients with subclinical } \\
\text { hypothyroidism }\end{array}$ & 35 individuals & $\begin{array}{l}\text { Sex may determine the effect of } \\
\text { metformin on hypothalamic- } \\
\text { pituitary-thyroid axis activity. }\end{array}$ & $\begin{array}{l}\text { Krysiak et al. } \\
2016 c\end{array}$ \\
\hline
\end{tabular}

penetrate the $\mathrm{BBB}$ reaching much higher levels in the pituitary than that in other brain regions (Labuzek et al. 2010). Impressively, pituitary gland is the brain region with the highest metformin accumulation achieved after its acute and chronic administration. Its concentration in the hypothalamus matched the level in plasma. Another study found that metformin induced upregulation of BBB actions via AMPK activation (Takata et al. 2013). However, the BBB is well known for its highly selective permeability, which allows the passage of water, some gases and lipid-soluble molecules by passive diffusion, as well as the selective transport of molecules such as glucose and amino acids that are crucial to neural function. Theoretically, metformin is not able to across the BBB due to its low molecular mass (168Da) and water solubility. No studies on the penetration of metformin to the BBB in human body have been performed so far; therefore, it still remains to be determined.

Other authors suggested that TSH-lowering effect of metformin may be explained by a metformin-induced activation of the adenosine monophosphate-activated protein kinase (AMPK), which is involved in a variety of cellular functions and regulates cellular energy metabolism (Duntas et al. 2011). Indeed, it may be plausible that any central effects of metformin on the TRH/TSH regulation involve the AMPK system. Metformin is proved to have an inhibitory effect on AMPK activity in the hypothalamus where it opposes $\mathrm{T}_{3}$ (Alevizaki 2013). http://joe.endocrinology-journals.org DOI: $10.1530 / J O E-16-0450$
(C) 2017 Society for Endocrinology Printed in Great Britain 
Another link between metformin and TSH may be IR. In a pilot study, metformin reduced elevated thyrotropin level in patients with interferon-induced hypothyroidism, as well as correlated with its impact on insulin sensitivity (Krysiak et al. 2016b). However, its clinical relevance is still unknown. A new study has found that in patients with $\mathrm{T}_{2} \mathrm{DM}$ and untreated amiodarone-induced hypothyroidism, metformin reduced serum level of thyrotropin and this effect correlated weakly with its action on insulin sensitivity (Krysiak et al. 2016a). This study also found that the effect of metformin on hypothalamic-pituitary-thyroid axis activity was partially related to thyroid function. Besides, metformin is not independently associated with TSH in $\mathrm{T}_{2} \mathrm{DM}$ patients with normal thyroid axis. More targeted studies are demanded to clarify the mechanisms of metformin action in the cases with activated TSH axis. A recent study has indicated that sex may determine the effect of metformin on hypothalamic-pituitary-thyroid axis activity, and only in women, metformin decreased serum TSH levels (Krysiak et al. 2016c).

Furthermore, it seems to be unlikely that metformin enhances gastrointestinal absorption of thyroid hormones in patients with hypothyroidism. In most studies, there was no increase of serum thyroid hormone level in response to metformin, irrespective of thyroxin replacement or not. A clinical study concluded that levothyroxine $\left(\mathrm{L}-\mathrm{T}_{4}\right)$ absorption is unchanged by concomitant metformin intake (Al-Alusi et al. 2015). In addition, metformin is not known to increase the absorption of any other nutrients or drugs.

\section{Clinical implications}

If the effect of metformin on TSH suppression is confirmed, metformin may be a useful adjunct for TSH suppression therapy as it appears to suppress serum TSH without causing biochemical hyperthyroxinemia or clinical hyperthyroidism. On the flip side, it increases the complexity of monitoring thyroid functional status in diabetic patients on metformin. Depressed TSH level provides false reassurance or may prompt initiation of therapy or endocrinologists may decrease $\mathrm{L}^{-\mathrm{T}_{4}}$ dosage with spuriously low TSH level. The clinicians should consider the effect of metformin when they interpret thyroid function to avoid any appropriate treatment or adjustment of $\mathrm{L}-\mathrm{T}_{4}$ dosage.

\section{Metformin and thyroid nodule and tumor}

\section{The pathogenesis of thyroid nodule}

Thyroid gland is a frequent site of abnormal epithelial cell proliferation, as demonstrated by the fact that the incidence of thyroid proliferative disease has risen rapidly over the past few years. Formation of thyroid nodule is due to the local enlargement of the thyroid caused by excessive growth and structural transformation of one or several areas within the normal thyroid gland. The etiology seems to involve complex interactions between environmental, iodine status, genetic and endogenous factors (Derwahl \& Studer 2001).

Recent findings demonstrated that insulin as a growth factor along with TSH stimulates thyroid cell proliferation and might be involved in the pathogenesis of thyroid growth and cancer development (Gursoy 2010). Patients with IR have larger thyroid volumes and higher risk for formation of thyroid nodules, and higher circulating levels of insulin are thought to increase thyroid proliferation and formation of thyroid nodules (Ittermann et al. 2013, Ogbera et al. 2012). One study hereof worth mentioning showed that development of thyroid nodule may depend on IR: in patients with small benign thyroid nodules and IR, metformin therapy was accompanied by a reduction in the nodular size, which was paralleled by a fall in TSH (Rezzonico et al. 2011). TSH via cAMP, and various growth factors, cooperated with insulin or insulin growth factor (IGF)-1 stimulates cell cycle progression and proliferation in various thyrocyte culture systems and primary cultures of different thyroid cell types (Kimura et al. 2001) (Fig. 1). On the other hand, TSH itself is a major regulator of growth and differentiation of thyroid cells and plays a role in nodule formation. In the presence of insulin in cell cultures, TSH is a well-known mitogen and also suppresses apoptotic cell death in response to various stimuli (Baser et al. 2016). This effect, at least in part, is mediated via IGF-I-dependent pathway; therefore, IGF1 might be involved in the pathogenesis of thyroid nodular growth and cancer development.

More importantly, rising world-wide incidence of thyroid cancer is also believed to be related to IR (Rezzonico et al. 2009), explained insulin/IGF1mediated growth stimulation. The insulin growth factors (IGFs) are potent mitogenic and anti-apoptotic factors and play a major role in a variety of human malignancies, including thyroid tumors (Kimura et al. 2001). The role of insulin itself in the pathogenesis

Published by Bioscientifica Ltd 


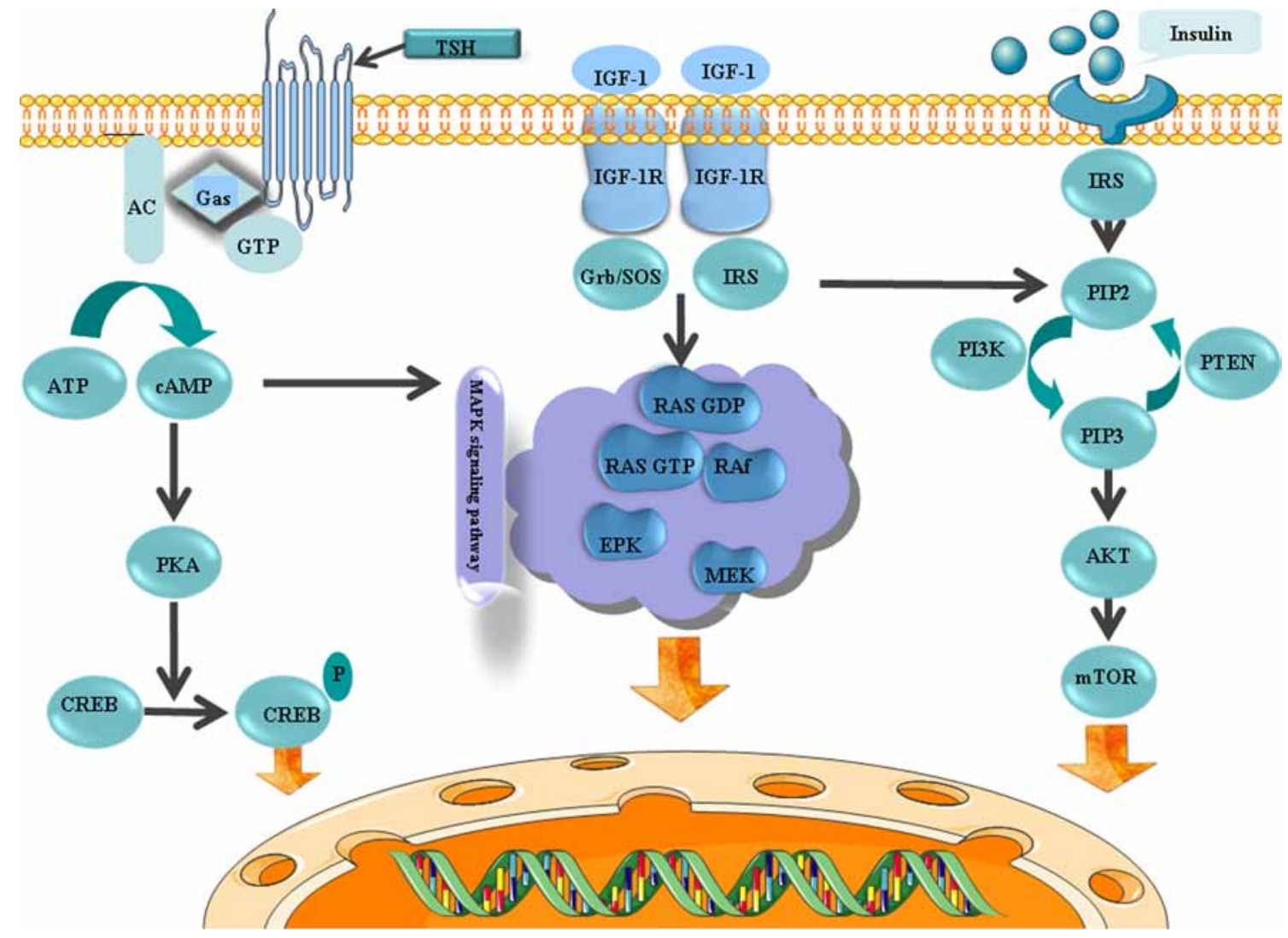

Figure 1

TSH and insulin/IGF1 axis in nodule formation. Insulin along with TSH functions as a growth factor and stimulates thyroid cell proliferation and might be involved in the pathogenesis of thyroid morphological abnormalities. The classical TSHR, MAPK and mTOR pathways acts on downstream effectors to modulate regulation of thyroid gene expression and other processes that may relate to thyrocyte proliferation, differentiation, malignant transformation. Arrows represent activation. This schematic overview shows the most important factors of the associated signaling network. Not all members of the signaling pathway are illustrated in order to be simplified.

of cancer is still debated, as insulin is not produced locally in thyroid cancer. However, its receptor may be activated by insulin homologs IGF1 and IGF-2, potent mitogenic factors produced locally in thyroid cancers (Díez \& Iglesias 2013). It was observed that expression of insulin receptor was increased in hypofunctioning benign thyroid adenomas, which lost differentiated functions such as iodine uptake. Therefore, overexpression or activation of insulin receptor may be an early event in thyroid tumorigenesis and nodular formation.

\section{Metformin and IR in thyroid nodules}

Metformin was found to antagonize the growthstimulatory effect of insulin in vitro (Chen et al. 2012). With addition of metformin, the insulin-induced increase of cell proliferation was almost abolished. As stated previously, hyperinsulinemia in patients with $T_{2} D M$ and/or prediabetes is associated with a higher incidence of benign and malignant tumors. A recent cross-sectional study also found a significant correlation between glycated hemoglobin and thyroid volume or the number of nodules (Blanc et al. 2015). Therefore, as an effective insulin-sensitizing drug, metformin may play a significant role in the adjuvant therapy of proliferative disease.

Given the impact of IR on the thyroid gland, Rezzonico et al. (2011) reported a retrospective study on 66 women with IR and nodular hyperplasia. A more pronounced reduction in nodule size was seen in patients treated with both metformin and $\mathrm{L}-\mathrm{T}_{4}$ compared to that in patients on metformin alone. The effect of metformin on shrinkage of thyroid nodule was accompanied by a fall in TSH concentration and normalization of the homeostasis model assessment (HOMA) index. Another randomized aforementioned placebo-controlled clinical trial also indicated that metformin can reduce the size of small solid thyroid nodules and prevent an increase

Published by Bioscientifica Ltd 
in the thyroid volume (Karimifar et al. 2014). Recently, a preliminary study also found that metformin therapy significantly decreased thyroid volume and nodule size in subjects with IR (Anil et al. 2016). Therefore, in patients with IR and nodular goiter, metformin may be a useful drug both to decrease IR and the size of solid nodules. By taking the role of TSH and IR in nodule formation into account, metformin may also be effective on prevention or treatment of thyroid nodule.

\section{Metformin and thyroid carcinoma}

Previous epidemiological studies have shown a positive relationship between IR and several common adult cancers, including differentiated thyroid carcinoma (DTC) (Gursoy 2010). Given the metformin-mediated improvements in insulin sensitivity, it was speculated that metformin results in a decreased prevalence of both IR and thyroid carcinoma. In fact, clinical trials have demonstrated that treatment with metformin was associated with higher remission rate and survival in diabetic patients with thyroid cancer (Klubo-Gwiezdzinska et al. 2013), and a favorable outcome in diabetic patients with cervical lymph node metastasis of DTC (Jang et al. 2015). Another large observational study in Taiwanese patients with $\mathrm{T}_{2} \mathrm{DM}$ showed that metformin reduced thyroid cancer risk (Tseng 2014). In a mouse model, metformin could block progression of obesity-activated thyroid cancer (Park et al. 2016). An opposite finding from Becker et al. (2015) indicated neither use of metformin nor of other antidiabetic drugs was associated with a decreased risk of thyroid cancer in a case-control study. Besides, a recent retrospective analysis found that metformin attenuated a 131I-induced decrease of peripheral blood cells in patients with DTC (Bikas et al. 2016).

Metformin was proved to inhibit the TNF- $\alpha$-induced CXCL8 secretion in primary cultures of human thyroid cells, acting as a further indirect anticancer property of the drug (Rotondi et al. 2015). Besides, in vitro study, our study showed that metformin exerted a growthinhibitory effect on primary thyrocytes and thyroid cancer cells by reducing hyperinsulinemia and by a direct cellular action, including inhibition of cell cycle progression and induction of apoptosis (Chen et al. 2012). Metformin markedly diminished growth stimulation by insulin on differentiated human thyroid cells, anaplastic thyroid carcinoma cells, a doxorubicin-resistant thyroid carcinoma cell line and thyroid cancer stem cells. In addition, an additive antimitogenic effect on chemotherapeutics agents was observed. In a recent study, sorafenib, a multikinase inhibitor used as alternative therapy for radioiodine-resistant DTC, combined with metformin synergistically decreased the proliferation of anaplastic thyroid cancer cell lines and the outgrowth of derived cancer stem cells (Chen et al. 2015). In papillary thyroid cancer, the therapeutic potential of metformin has also been identified both in vitro and in vivo (Cho et al. 2014). Another study on medullary thyroid carcinoma (MTC) cell lines showed that metformin inhibited growth and induced anoikis in MTC-derived cells, suggesting that metformin inhibits growth and prevents the development of metastases in MTC (Klubo-Gwiezdzinska et al. 2012). In addition, metformin may inhibit the growth, migration and mesenchymal transition of thyroid cancer cell lines by the mTOR pathway beyond insulin/IGF1 pathway (Han et al. 2015).

The suppressive effect of metformin on TSH level suggests a need for dose reduction of $\mathrm{L}_{-} \mathrm{T}_{4}$ in postoperative hypothyroid patients receiving TSH-suppressive therapy and metformin treatment. In a retrospective clinical study on patients undergoing total thyroidectomy, for TSH suppression, a lower thyroxin dose was observed in patients treated with metformin, when compared to that in patients without metformin (Casteras et al. 2013). However, the results of this study were controversially discussed due to different characteristics (greater weight and age) of the patients in metformin-treated and control groups. Another single-blind randomized controlled trial found that adding $500 \mathrm{mg}$ of metformin did not enable $\mathrm{L}-\mathrm{T}_{4}$ dose reduction in patients with DTC (Mousavi et al. 2014). On the other hand, we have to take this fact with caution as the effect of metformin can be related to changes in the hypothalamus-pituitary axis, and the dose reduction may cause symptoms of hypothyroidism to patients as peripheral tissues may need more $\mathrm{L}-\mathrm{T}_{4}$. Therefore, the exact role of metformin in patients on TSHsuppressive therapy after ablative treatment for thyroid cancer is still the subject of discussion.

\section{Conclusions and future perspectives}

In the last decade, several clinical studies demonstrated that metformin may have a TSH-lowering effect. Apart from this, metformin was found to reduce the nodular volume, inhibit the growth of thyroid carcinoma and potentiate the antimitogenic effect of chemotherapeutic agents. These findings suggest a broader use of this drug not only for type 2 diabetics with or without proliferative

Published by Bioscientifica Ltd. 
thyroid disease but also for those with metabolic syndrome and obesity. However, more associated studies are necessary to analyze the effects of metformin in these patients.

\section{Declaration of interest}

The authors declare that there is no conflict of interest that could be perceived as prejudicing the impartiality of this review.

\section{Funding}

The authors gratefully acknowledge the grant support of National Natural Science Foundation of China (grant number: 81200577).

\section{References}

Al-Alusi MA, Du L, Li N, Yeh MW, He X, Braverman LE \& Leung AM 2015 Metformin does not suppress serum thyrotropin by increasing levothyroxine absorption. Thyroid 25 1080-1084. (doi:10.1089/ thy.2015.0211)

Alevizaki M 2013 Metformin and the thyroid: some questions still remain. Clinical Endocrinology 78 503-504. (doi:10.1111/cen.12005)

Anil C, Akkurt A, Ayturk S, Kut A \& Gursoy A 2013 Impaired glucose metabolism is a risk factor for increased thyroid volume and nodule prevalence in a mild-to-moderate iodine deficient area. Metabolism 62 970-975. (doi:10.1016/j.metabol.2013.01.009)

Anil C, Kut A, Atesagaoglu B, Nar A, Bascil Tutuncu N \& Gursoy A 2016 Metformin decreases thyroid volume and nodule size in subjects with insulin resistance: a preliminary study. Medical Principles and Practice 25 233-236. (doi:10.1159/000442821)

Baser H, Topaloglu O, Tam AA, Evranos B, Alkan A, Sungu N, Dumlu EG, Ersoy R \& Cakir B 2016 Higher TSH can be used as an additional risk factor in prediction of malignancy in euthyroid thyroid nodules evaluated by cytology based on Bethesda system. Endocrine $\mathbf{5 3}$ 520-529. (doi:10.1007/s12020-016-0919-4)

Becker C, Jick SS, Meier CR \& Bodmer M 2015 No evidence for a decreased risk of thyroid cancer in association with use of metformin or other antidiabetic drugs: a case-control study. BMC Cancer 15719. (doi:10.1186/s12885-015-1719-6)

Bikas A, Van Nostrand D, Jensen K, Desale S, Mete M, Patel A, Wartofsky L, Vasko V \& Burman KD 2016 Metformin attenuates 131I-induced decrease in peripheral blood cells in patients with differentiated thyroid cancer. Thyroid 26 280-286. (doi:10.1089/ thy.2015.0413)

Blanc E, Ponce C, Brodschi D, Nepote A, Barreto A, Schnitman M, Fossati P, Salgado P, Cejas C, Faingold C, et al. 2015 Association between worse metabolic control and increased thyroid volume and nodular disease in elderly adults with metabolic syndrome. Metabolic Syndrome and Related Disorders 13 221-226. (doi:10.1089/ met.2014.0158)

Cappelli C, Rotondi M, Pirola I, Agosti B, Gandossi E, Valentini U, De Martino E, Cimino A, Chiovato L, Agabiti-Rosei E, et al. 2009 TSH-lowering effect of metformin in type 2 diabetic patients: differences between euthyroid, untreated hypothyroid, and euthyroid on L-T4 therapy patients. Diabetes Care 32 1589-1590. (doi:10.2337/ dc09-0273)

Cappelli C, Rotondi M, Pirola I, Agosti B, Formenti A, Zarra E, Valentini U, Leporati P, Chiovato L \& Castellano M 2012 Thyreotropin levels in diabetic patients on metformin treatment. European Journal of Endocrinology 167 261-265. (doi:10.1530/EJE-120225)
Casteras A, Zafon C, Ciudin A \& Mesa J 2013 Are levothyroxine requirements lower in thyroidectomized diabetic patients on metformin treatment? Thyroid 23 1510-1513. (doi:10.1089/thy.2013.0114)

Chen G, Xu S, Renko K \& Derwahl M 2012 Metformin inhibits growth of thyroid carcinoma cells, suppresses self-renewal of derived cancer stem cells, and potentiates the effect of chemotherapeutic agents. Journal of Clinical Endocrinology and Metabolism 97 E510-E520. (doi:10.1210/jc.2011-1754)

Chen G, Nicula D, Renko K \& Derwahl M 2015 Synergistic antiproliferative effect of metformin and sorafenib on growth of anaplastic thyroid cancer cells and their stem cells. Oncology Reports 33 1994-2000. (doi:10.3892/or.2015.3805)

Cho SW, Yi KH, Han SK, Sun HJ, Kim YA, Oh BC, Park YJ \& Park do J 2014 Therapeutic potential of metformin in papillary thyroid cancer in vitro and in vivo. Molecular and Cellular Endocrinology 393 24-29. (doi:10.1016/j.mce.2014.05.021)

Derwahl M \& Studer H 2001 Nodular goiter and goiter nodules: where iodine deficiency falls short of explaining the facts. Experimental and Clinical Endocrinology \& Diabetes 109 250-260. (doi:10.1055/s-2001-16344)

Díez JJ \& Iglesias P 2013 Relationship between serum thyrotropin concentrations and metformin therapy in euthyroid patients with type 2 diabetes. Clinical Endocrinology 78 505-511. (doi:10.1111/ j.1365-2265.2012.04468.x)

Distiller LA, Polakow ES \& Joffe BI 2014 Type 2 diabetes mellitus and hypothyroidism: the possible influence of metformin therapy. Diabetic Medicine 31 172-175. (doi:10.1111/dme.12342)

Duntas LH, Orgiazzi J \& Brabant G 2011 The interface between thyroid and diabetes mellitus. Clinical Endocrinology 75 1-9. (doi:10.1111/ j.1365-2265.2011.04029.x)

Fournier JP, Yin H, Yu OH \& Azoulay L 2014 Metformin and low levels of thyroid-stimulating hormone in patients with type 2 diabetes mellitus. CMAJ 186 1138-1145. (doi:10.1503/cmaj.140688)

Giannarelli R, Aragona M, Coppelli A \& Del Prato S 2003 Reducing insulin resistance with metformin: the evidence today. Diabetes \& Metabolism 29 6S28-6S35. (doi:10.1016/s1262-3636(03)72785-2)

Gursoy A 2010 Rising thyroid cancer incidence in the world might be related to insulin resistance. Medical Hypotheses 74 35-36. (doi:10.1016/j.mehy.2009.08.021)

Han B, Cui H, Kang L, Zhang X, Jin Z, Lu L \& Fan Z 2015 Metformin inhibits thyroid cancer cell growth, migration, and EMT through the mTOR pathway. Tumour Biology 36 6295-6304. (doi:10.1007/s13277015-3315-4)

Isidro ML, Penín MA, Nemiña R \& Cordido F 2007 Metformin reduces thyrotropin levels in obese, diabetic women with primary hypothyroidism on thyroxine replacement therapy. Endocrine $\mathbf{3 2}$ 79-82. (doi:10.1007/s12020-007-9012-3)

Ittermann T, Markus MR, Schipf S, Derwahl M, Meisinger C \& Volzke H 2013 Metformin inhibits goitrogenous effects of type 2 diabetes. European Journal of Endocrinology 169 9-15. (doi:10.1530/EJE-13-0101)

Jang EK, Kim WG, Kwon H, Choi YM, Jeon MJ, Kim TY, Shong YK, Kim WB \& Kim EY 2015 Metformin is associated with a favorable outcome in diabetic patients with cervical lymph node metastasis of differentiated thyroid cancer. European Thyroid Journal 4 181-188. (doi:10.1159/000437365)

Karimifar M, Aminorroaya A, Amini M, Mirfendereski T, Iraj B, Feizi A \& Norozi A 2014 Effect of metformin on thyroid stimulating hormone and thyroid volume in patients with prediabetes: a randomized placebo-controlled clinical trial. International Journal of Research in Medical Sciences 19 1019-1026.

Kimura T, Van Keymeulen A, Golstein J, Fusco A, Dumont JE \& Roger PP 2001 Regulation of thyroid cell proliferation by TSH and other factors: a critical evaluation of in vitro models. Endocrine Reviews 22 631-656. (doi:10.1210/edrv.22.5.0444)

Klubo-Gwiezdzinska J, Jensen K, Costello J, Patel A, Hoperia V, Bauer A, Burman KD, Wartofsky L \& Vasko V 2012 Metformin inhibits growth

Published by Bioscientifica Ltd. 
and decreases resistance to anoikis in medullary thyroid cancer cells. Endocrine-Related Cancer 19 447-456. (doi:10.1530/ERC-12-0046)

Klubo-Gwiezdzinska J, Costello Jr J, Patel A, Bauer A, Jensen K, Mete M, Burman KD, Wartofsky L \& Vasko V 2013 Treatment with metformin is associated with higher remission rate in diabetic patients with thyroid cancer. Journal of Clinical Endocrinology and Metabolism 98 3269-3279. (doi:10.1210/jc.2012-3799)

Kouidhi S, Berhouma R, Ammar M, Rouissi K, Jarboui S, ClergetFroidevaux MS, Seugnet I, Abid H, Bchir F, Demeneix B, et al. 2013 Relationship of thyroid function with obesity and type 2 diabetes in euthyroid Tunisian subjects. Endocrine Research 38 15-23. (doi:10.3109/ 07435800.2012.699987)

Krysiak R \& Okopien B 2011 Thyrotropin-lowering effect of metformin in a patient with resistance to thyroid hormone. Clinical Endocrinology 75 404-406. (doi:10.1111/j.1365-2265.2011.04058.x)

Krysiak R \& Okopien B 2015 The effect of metformin on the hypothalamic-pituitary-thyroid axis in women with polycystic ovary syndrome and subclinical hypothyroidism. Journal of Clinical Pharmacology 55 45-49. (doi:10.1002/jcph.373)

Krysiak R, Szkrobka W \& Okopien B 2015 The effect of metformin on the hypothalamic-pituitary-thyroid axis in patients with type 2 diabetes and subclinical hyperthyroidism. Experimental and Clinical Endocrinology \& Diabetes 123 205-208. (doi:10.1055/s-0034-1398621)

Krysiak R, Gilowska M, Szkrobka W \& Okopien B 2016a The effect of metformin on the hypothalamic-pituitary-thyroid axis in patients with type 2 diabetes and amiodarone-induced hypothyroidism. Pharmacological Reports 68 490-494. (doi:10.1016/j.pharep.2015.11.010)

Krysiak R, Szkrobka W \& Okopien B $2016 b$ The effect of metformin on hypothalamic-pituitary-thyroid axis activity in women with interferon-induced hypothyroidism: a pilot study. Experimental and Clinical Endocrinology \& Diabetes 124 71-76. (doi:10.1055/s-0042-101163)

Krysiak R, Szkrobka W \& Okopien B 2016c Sex-dependent effect of metformin on hypothalamic-pituitary-thyroid axis activity in patients with subclinical hypothyroidism. Pharmacological Reports 68 1115-1119. (doi:10.1016/j.pharep.2016.07.002)

Labuzek K, Suchy D, Gabryel B, Bielecka A, Liber S \& Okopien B 2010 Quantification of metformin by the HPLC method in brain regions, cerebrospinal fluid and plasma of rats treated with lipopolysaccharide. Pharmacological Reports 62 956-965. (doi:10.1016/S17341140(10)70357-1)

Lupoli R, Di Minno A, Tortora A, Ambrosino P, Lupoli GA \& Di Minno MN 2014 Effects of treatment with metformin on TSH levels: a meta-analysis of literature studies. Journal of Clinical Endocrinology and Metabolism 99 E143-E148. (doi:10.1210/jc.2013-2965)

Morteza Taghavi S, Rokni H \& Fatemi S 2011 Metformin decreases thyrotropin in overweight women with polycystic ovarian syndrome and hypothyroidism. Diabetes and Vascular Disease Research 8 47-48. (doi:10.1177/1479164110391917)

Mousavi Z, Dourandish L, Rokni H, Sadeghi R \& Rasoul Zakavi S 2014 Effects of short-term metformin therapy associated with levothyroxine dose decrement on TSH and thyroid hormone levels in patients with thyroid cancer. Minerva Endocrinologica 39 59-65.

Ogbera AO, Kuku S \& Dada O 2012 The metabolic syndrome in thyroid disease: a report from Nigeria. Indian Journal of Endocrinology and Metabolism 16 417-422. (doi:10.4103/2230-8210.95688)

Park J, Kim WG, Zhao L, Enomoto K, Willingham M \& Cheng SY 2016 Metformin blocks progression of obesity-activated thyroid cancer in a mouse model. Oncotarget 7 34832-34844. (doi:10.18632/ oncotarget.8989)

Rezzonico JN, Rezzonico M, Pusiol E, Pitoia F \& Niepomniszcze H 2009 Increased prevalence of insulin resistance in patients with differentiated thyroid carcinoma. Metabolic Syndrome and Related Disorders 7 375-380. (doi:10.1089/met.2008.0062)

Rezzonico J, Rezzonico M, Pusiol E, Pitoia F \& Niepomniszcze H 2011 Metformin treatment for small benign thyroid nodules in patients with insulin resistance. Metabolic Syndrome and Related Disorders 9 69-75. (doi:10.1089/met.2010.0026)

Rotondi M, Cappelli C, Magri F, Botta R, Dionisio R, Iacobello C, De Cata P, Nappi RE, Castellano M \& Chiovato L 2011 Thyroidal effect of metformin treatment in patients with polycystic ovary syndrome. Clinical Endocrinology 75 378-381. (doi:10.1111/j.13652265.2011.04042.x)

Rotondi M, Coperchini F, Pignatti P, Magri F \& Chiovato L 2015 Metformin reverts the secretion of CXCL8 induced by TNF-alpha in primary cultures of human thyroid cells: an additional indirect anti-tumor effect of the drug. Journal of Clinical Endocrinology and Metabolism 100 E427-E432. (doi:10.1210/jc.2014-3045)

Santos-Palacios S, Brugos-Larumbe A, Guillen-Grima F, GarmendiaMadariaga A \& Galofre JC 2015 Does metformin have a "buffer effect" on serum TSH levels in euthyroid diabetic patients? Hormones $\mathbf{1 4}$ 280-285. (doi:10.14310/horm.2002.1559)

Takata F, Dohgu S, Matsumoto J, Machida T, Kaneshima S, Matsuo M, Sakaguchi S, Takeshige Y, Yamauchi A \& Kataoka Y 2013 Metformin induces up-regulation of blood-brain barrier functions by activating AMP-activated protein kinase in rat brain microvascular endothelial cells. Biochemical and Biophysical Research Communications $\mathbf{4 3 3}$ 586-590. (doi:10.1016/j.bbrc.2013.03.036)

Tseng CH 2014 Metformin reduces thyroid cancer risk in Taiwanese patients with type 2 diabetes. PLOS ONE 9 e109852. (doi:10.1371/ journal.pone.0109852)

Vigersky RA, Filmore-Nassar A \& Glass AR 2006 Thyrotropin suppression by metformin. Journal of Clinical Endocrinology and Metabolism 91 225-227. (doi:10.1210/jc.2005-1210)

Received in final form 27 November 2016

Accepted 4 January 2017

Accepted Preprint published online 14 February 2017
๑) 2017 Society for Endocrinology Printed in Great Britain
Published by Bioscientifica Ltd 